Volume: 7 Issue: 14 Year: 2021

\title{
Covid-19 Sürecinde Akademisyenlerin Acil Uzaktan Eğitim Sistemi Kullanım Algılarının Planlı Davranış Teorisi Temelinde Teknoloji Kabul Modeli ile İncelenmesi
}

Öğr. Gör. Fevziye BEKAR

Gümüşhane Üniversitesi

Şiran sağlık Hizmetleri MYO

ORCID: 0000000316924294

\author{
Doç. Dr. Handan Çam \\ Gümüşhane Üniversitesi \\ İktisadi ve İdari Bilimler Fakültesi \\ ORCID: 0000000309822919
}

\section{Özet}

Yeni Koronavirüs salgını esnasında yüz yüze eğitim sisteminden acil uzaktan eğitime geçilmiştir. Bu değişime yönelik olarak çalışmanın amacı, akademisyenlerin acil uzaktan eğitim sistemini nasıl algıladıkları, algılarını etkileyen faktörlerin neler olduğunu belirlemektir. Araştırma kapsamında planlanmış davranış teorisi temelinde teknoloji kabul modeli kullanılmıştır. Araştırmanın evrenini akademisyenler oluşturmaktadır. Kolayda ve kartopu örneklem yöntemi kullanılarak 43 farklı üniversitede görev yapmakta olan 444 akademisyene ulaşılmıştır. Araştırmanın verileri, Google forms aracılığıyla oluşturulan çevrimiçi anket formu aracılığı elde edilmiştir. Elde edilen verilere ait güvenirlik, geçerlilik ve doğrulayıcı faktör analizleri yapılıp araştırma modeli yapısal eşitlik modeli aracılığıyla sınanmıştır. Yapısal eşitlik analizi sonucunda çalışmada önerilen 9 hipotezden yedisi kabul edilmiştir. Araştırma sonucuna göre, planlanmış davranış teorisi temelinde ele alınan öznel norm (kişiler arası etki ve dış etki) değişkenlerinin davranışsal niyet üzerinde etkisinin olmadığı; algılanan fayda ve algılanan kullanım kolaylığının uzaktan eğitim sisteminin 
kullanımına yönelik tatmini pozitif ve anlamlı yönde etkilediği, tatminin ve algılanan davranışsal kontrolün davranışa yönelik niyeti pozitif ve anlamlı olarak etkilediği; davranışa yönelik niyetin ise uzaktan eğitimin kullanıma yönelik gerçekleşen davranışı pozitif ve anlamlı yönde etkilediği sonucuna ulaşılmıştır.

Anahtar Kelimeler: Yeni Koronavirüs Salgını, Teknoloji Kabul Modeli, Planlı davranış Teorisi, Acil Uzaktan Eğitim Sistemi, Akademisyenler

\title{
An Analysis of Academics' User Perceptions of Emergency Distance Education Systems within COVID-19 based on the Theory of Planned Behavior Using Technology Acceptance Model
}

\begin{abstract}
Face-to-face education gave way to online emergency education due to the new Coronavirus pandemic. Regarding this change, this study aims to determine how academics perceive emergency distance education systems and the factors that affect their perceptions. Technology Acceptance Model was used for the theory of planned behaviour in this study. The population consisted of academics. Convenience and snowball sampling methods were used to reach the 444 academics that work in 43 different universities. The data were collected with online questionnaire forms through Google Forms. The collected data were tested through reliability, validity and confirmatory factor analyses and the research model was reviewed through the structural equation model. As a result, seven out of the nine suggested hypotheses were accepted. The research concluded that the subjective norm variables based on the theory of planned behaviour such as interpersonal effects and external effects did not have an impact on behavioural intention; perceived usefulness and perceived ease of use had a significantly positive effect on satisfaction towards the use of distant education; satisfaction and perceived behavioural control had a significantly positive effect on behaviour and that behavioural intention had a significantly positive effect on behaviour towards the use of distant education.
\end{abstract}

Keywords: New Coronavirus Pandemic, Technology Acceptance Model, Theory of Planned Behaviour, Emergency Distance Education System, Academics 


\section{Giriş}

Küreselleşmeye dayalı ülke sınırlarının ortadan kalkması, ülkeler arası işbirliklerin artması çoğu noktada fayda sağlarken bu durum olumsuzluklar ile de sonuçlanabilmektedir. COVID-19 salgını bu olumsuzluklar adına gösterilebilecek en önemli örnek olabilmektedir. Çünkü şuan tek bir ülke de değil tüm dünya gelinde ekonomik, sosyal, psikolojik, sosyolojik olmak üzere çok farkl1 açılardan problemler ortaya çıkmıştır (Eken, Tosun ve Eken, 2020).

Günümüzde hala etkisi devam etmekte olan COVID-19 salgınından etkilenen sektörlerden biriside eğitim sektörü olmuştur. 2019-2020 eğitim yılı bahar yarıyılı içerisinde 26 Mart 2020 tarihinde Yüksek Öğretim Kurumu (YÖK) yüz yüze eğitimin yapılamayacağını ilan etmiştir. Eğitim sürecinin aksamaması içinde alternatif olarak acil uzaktan eğitim sürecine geçilmiştir (Kürtüncü ve Kurt, 2020: 68). 1970'li yıllardan itibaren kullanılan uzaktan eğitim sistemi olağanüstü bir durum sebebiyle en yoğun olarak salgın sürecinde kullanılmıştır (Eken, Tosun ve Eken, 2020). Günümüzde de etkisi hala sürmekte olan COVID-19 salgını esnasında uzaktan eğitim sisteminin zorunlu, ihtiyacı karşılaması için kullanılması, kriz sürecinde planlı bir şekilde olmadan yüz yüze eğitim öğretiminin aniden terk edilmesi, çevrimiçi bağlantıya dayalı bir öğretim sistemine geçilmesi sebepleriyle bu süreç “acil uzaktan eğitim” kavramı ile anılmaya başlanmaktadır. Çünkü uzaktan eğitim sistemi acil uzaktan eğitiminin aksine, planlı bir şekilde yaşam boyu öğrenmeyi hedef alarak sürdürülebilir bir nitelikte kurumsal uygulamayı ve sistematik olmay1 hedeflemektedir (Bozkurt ve diğ., 2020; Bozkurt, 2020).

Böylesine plansız bir eğitim-öğretim sürecine geçilmesi beraberinde bu sürecin nasıl bir şekilde işleyeceği hakkında bilgi eksikliğinden ve bu belirsizlikten kaynaklı olarak başta stres, kaygı olmak üzere çok çeşitli psikolojik problemlerde bu süreçten kaynaklı olarak açığa çıkmıştır. Bu süreçteki stres ve kaygı oranlarını artırıcı diğer bir unsur ise, acil uzaktan eğitim sürecine ait alt yapı sorunlarının ders verme ve sınav süreçlerinde de devam etmesidir. Bu problemlerin karşısında bu stresli süreç ile başa çıkabilmek için öncelikle eğitim sektörüne ait uzaktan eğitimi kullanan tarafların (akademisyen, öğretmen, öğrenci, veli vb.) algılarını ölçmek için teknoloji kabul modeli tercih edilmiştir. Çoğu araştırmacı teknoloji kabul modelini kullanarak bu süreç hakkında kullanıcıların niyet, tutum ve davranışlarına dair bilgi edinmeyi ve edinilen bilgiler 1şı̆̆ında öneriler geliştirmeyi amaçlamışlardır (örneğin, Yörük, Akar ve Erdoğan, 2020; Hong ve diğ., 
2021; Lazim ve diğ., 2021; Farooq ve diğ., 2021; Girish ve diğ., 2021; Shanthi ve diğ, 2021; Avc1 ve Y1ld1z, 2021).

Davis (1989) tarafından ortaya konulan teknoloji kabul modelinin temelde 4 bileșeni bulunmaktadır. Bunlar: kullandıkları teknolojilerden ne kadar yarar sağlayacaklarına yönelik edindikleri bilgi düzeyini ifade eden algılanan fayda (1), bireylerin teknoloji kullanımına yönelik algıladıkları kolaylık düzeyini belirten algllanan kullanım kolaylı̆̆(2), bireylerin teknoloji kullanmalarına yönelik edinmiş oldukları olumlu ya olumsuz tecrübeler neticesinde teknoloji kullanım isteğini ölçen davranışsal niyet (3) ve teknoloji kullanmalarına yönelik niyetleri sonucunda ortaya koymuş oldukları gerçekleşen davranıştır (4) (Sukendro ve diğ, 2020; Lazim ve diğ, 2021; Hong, Zhang ve Liu,2021).

Bu bilgiler 1şığında bu araştırmanın asıl amacı, COVID-19 sürecinde acil uzaktan eğitim esnasında akademisyenlerin kulanmış oldukları uzaktan eğitim sistemine yönelik algılarını ve bu sürece ait algılarını etkileyen unsurları, bu unsurların birbirleri arasındaki neden sonuç ilişkisini ortaya koymaktır. Bunu yaparken ise, planlı davranış teorisi temelinde bu araştırmayı irdelemekteyiz.

Fishbein ve Ajzen (1975) tarafindan ortaya atılıp Ajzen (1991) tarafinda geliştirilen planlı davranış teorisinin temel varsayımları ile teknoloji kabul modelinin bileşenleri örtüşmektedir. Planlı davranış teorisine göre, bireyler belirli sebepler sonucunda bir davranışta bulunurlar. $\mathrm{Bu}$ davranışlarda bulunmadan önce belirli bir amaca sahiptirler. Amaçlar niyetlere, niyetler ise tutumlara dönüşmektedir. Sonuç olarak ise, inançları davranışa dönüşmektedir. Planlı davranış teorisinde, teknoloji kabul modelinin temel bileşenlerinden farklı olarak, öznel norm ve algılanan davranışsal kontrol kavramları mevcuttur. Yani bireylerin inançlarının, öznel norm, algılanan davranışsal kontroller tarafından etkilenmekte ve davranışa yönelik tutumlar dönüşmektedir. Öznel norm, bireylerin bir davranışta bulurken referans aldığı, güvendiği kaynaklardır. Bu bir kurum ya da bir kişi olabilmektedir. Algılanan davranış kontrolü ise, bir kişinin eylemde bulunacağı davranışın gerçekleştirilmesi noktasında sahip olduğu güç düzeyidir (Ajzen, 1991; Conner ve Armitage, 1998; Erten, 2002).

Yukarıda belirtilenler ışı̆̆ında, kolayda ve kartopu örneklem yöntemini kullanılarak oluşturulan çevrimiçi anket neticesinde 444 akademisyene ulaşılmıştır. Planlı davranış teorisi temelinde teknoloji kabul modeli ela alınarak akademisyenlerin acil uzaktan eğitim sürecine yönelik algıları hakkında bilgi edinilmiştir. Araştırmanın yazın tasarımına göre, öncelikle mevcut alan yazındaki 
örnek çalışmalara, araştırmanın yöntemine ve sonuç kısmına değinilerek araştırmanın yazını sonlandırılacaktır.

\section{COVID-19 Salgını Süreci ve Teknoloji Kabul Modeline Ait Yürütülen Araştırmalar}

Sukendro ve diğ, (2020), spor bilimlerinde eğitim almakta olan öğrenciler üzerinde uzaktan eğitim sürecine yönelik algılarını ölçmek amacıyla teknoloji kabul modelini kullanmıştır. Araştırma kapsamında rastgele örneklem yöntemi ve çevrim içi anket verisi toplama yöntemi kullanılarak 974 öğrenciye ulaşılmıştır. Araştırma sonucunda, dış değişken olarak ele alınan kolaylaştırıcı koşulların algılanan kullanım kolaylığı ve algılanan fayda üzerinde pozitif ve anlamlı bir etkisi olduğu; algılanan kullanım kolaylı̆̆ının, algılanan faydayı ve ve tutumu olumlu yönde etkilediği; algılanan faydanın davranışsal niyeti olumlu yönde etkilediği, tutumun davranışsal niyeti, davranışsal niyetinde uzaktan eğitim sürecinde öğrenmeyi olumlu yönde etkilediği sonucuna ulaşılmıştır. Fakat araştırma sonucuna göre algılanan faydanın tutum üzerinde anlamlı bir etkisi olmadığı sonucuna ulaşılmamıştır.

Grish ve diğ., (2021), COVID-19 salgını esnasında, öğrencilerin uzaktan eğitim sistemine yönelik algılarını test etmek amacıyla teknoloji kabul modelini kullanmıştır. Kolayda örneklem yöntemi kullanarak Hindistan'da eğitim almakta olan 288 öğrenci üzerine bu araştırmayı gerçekleştirmiştir. Araştırma sonucunda, internet tabanlı öğrenme etkileşiminin algılanan kullanım kolaylığı ve algılanan fayda üzerinde pozitif bir etkisi olduğu, algılanan fayda ve kullanım kolaylığının tutum üzerinde pozitif bir etkisi olduğu, tutumun ise uzaktan öğrenme sisteminin kullanım niyetini pozitif yönde etkilediği sonucuna ulaşılmıştır. Aynı zamanda bu araştırmada COVID-19 salgınına yönelik algılanan risk ve belirsizlikten kaçınma davranışının tutum ve uzaktan eğitimi kullanma niyeti üzerindeki etkisini de incelemiştir. Araştırma sonucunda, COVID-19 salgınına yönelik algılanan risk ile uzaktan eğitime yönelik kullanım algısı arasında negatif bir ilişkinin mevcut olduğu sonucuna ulaşılmıştır.

Farooq ve diğ., (2021) tarafından, Pakistan'daki bir üniversitede 495 öğrenci üzerinde bir araştırma yürütülmüştür. Algılanan kullanım kolaylığı, öznel norm, algılanan fayda, sisteme erişilebilirlik, 
tutum, davranışsal niyet değişkenleri arasındaki ilişkileri incelemiştir. Araştırma neticesinde, sisteme erişilebilirlik ile algılanan fayda, öznel norm ile uzaktan eğitim bir ilişki bulunamamıştır.

COVID-19 salgını sürecinde teknoloji kabul modeli temelinde kolayda örneklem yöntemini kullanarak 1259 öğrenci üzerine Avcı ve Yıldız (2021) tarafindan da bir araştırma yürütülmüştür. Algılanan kullanım kolaylığı, performans beklentisi, algılanan fayda, memnuniyet, davranışsal niyet değişkenleri arasındaki ilişkiye odaklanılmıştır. Araştırma sonucunda, algılanan kullanım kolaylığının memnuniyet ve davranışsal niyet üzerinde bir etkisi olmadığı sonucuna ulaşılmıştır. Aynı zamanda algılanan faydanın davranışsal niyet üzerinde bir etkisi olmadığı sonucuna ulaşılmışıtır. COVID-19 süresince Kâhya (2021), Rini ve Khasanah (2021) olmak üzere çok fazla araştırmacı tarafindan teknoloji kabul modeli temelinde araştırmalar yürütülmüştür.

\section{Araştırmanın Metedolojisi}

\subsection{Araştırmanın Tasarımı ve Örneklemi}

Araştırma, hem mesleki tecrübeye dayalı olarak hem de alan yazındaki eksiklikten yola çıkılarak tasarlanmıştır. Bu kapsamda, 2020/06 sayı ve 11/06/2020 tarihli Gümüşhane üniversitesi bilimsel araştırma ve yayın etiği kurulu toplantısından alınan karar ile 17.06.2020 tarihli 95674917-108.99E.14995 sayılı iç yazı ile birlikte araştırma süreci başlatılmıştır.

Araştırmanının evrenini, 2019-2020 tarihlerinde Türkiye'de faaliyette bulunan toplam 207 üniversitede görev yapmakta olan 179. 685 akademisyenler oluşturmaktadır (Yükseköğretim Bilgi Yönetim Sistemi, https://istatistik.yok.gov.tr/). Üniversitenin elektronik bilgi paylaşım sistemi kullanılarak anket paylaşımının yapılması ve veri toplanması için 2.10.2020-25.02.2021 tarihleri arasında Türkiye'deki bütün üniversiteler bilgi yazısı gönderilmiştir. 43 farklı üniversiteden izin verildiğine dair dönüş yapılarak araştırma bu üniversitelerden gelen izin yazıları sonucunda kolayda ve kartopu örneklem yöntemi kullanılarak Google Forms platformundan oluşturulan çevrimiçi anket yöntemi ile yürütülmüştür. Araştırma neticesinde 444 akademisyene ulaşılmıştır. Baş'a (2008: 40) göre, 100.000 - 1.000 .000 hedef kitlesine sahip araştırma evreni için \% 95 güven aralığında örneklem büyüklüğünün 384 kişinin yeterli olacağı belirtilmektedir. Bu yönü ile örneklem büyüklüğünün yeterli sayıda olduğu düşünülmektedir. 
Doğan vd. (2015) araştırması temel alınarak, Şekil 1'de araştırmanın modeli sunulmuştur. Ardından ise araştırmanın hipotezlerine yer verilmiştir.

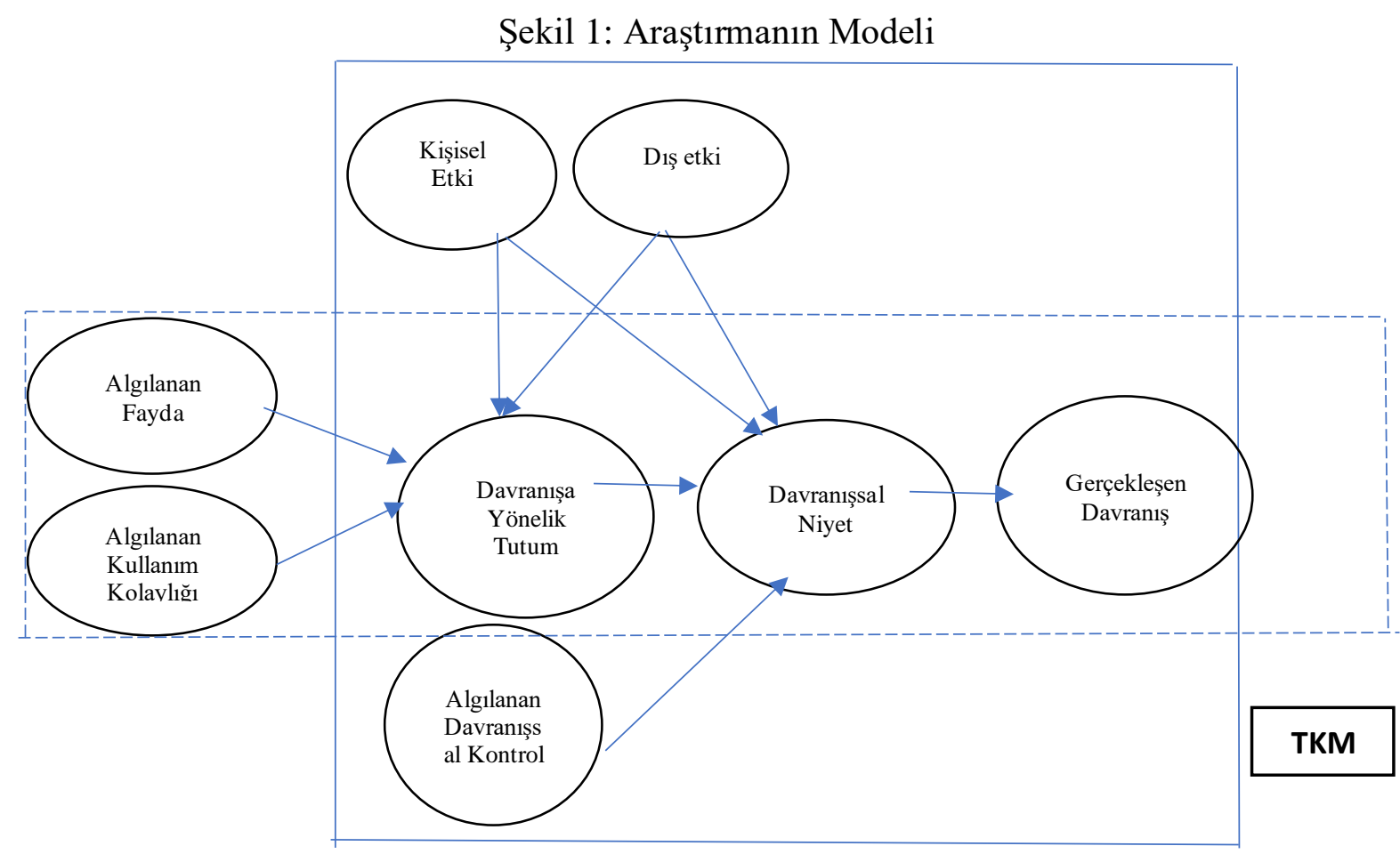

\section{PDT}

TKM (Teknoloji Kabul Modeli)

PDT (Planlı Davranış Teorisi

Doğan vd. (2015)'e göre, kesikli çizgiler Planlı Davranış Teorisi ile Teknoloji Kabul Modellerinde mevcut olan ortak faktörlerin birleştirilmiş halini ifade etmektedir.

Doğan ve diğg, (2015) araştırması temelinde COVID-19 salgını sürecine dayalı olarak acil uzaktan eğitime yönelik temel varsayımlar aşağıdaki şekilde oluşturulmuştur. 
H1: Kullanıcıların acil uzaktan eğitim sistemine ilişkin algıladı̆̆ 1 fayda düzeyi, onların bu sistemi kullanımlarına yönelik tutumlarını (tatmin) olumlu yönde etkilemektedir.

H2: Kullanıcıların acil uzaktan eğitim sistemine ilişkin algıladı̆̆ı kullanım kolaylı̆̆ı, onların uzaktan eğitim sistemini kullanımlarına yönelik tutumlarını (tatmin) olumlu yönde etkilemektedir.

H3: Kullanıcıların acil uzaktan eğitim sistemine ilişkin öznel normları (kişilerarası etki, H3a; dış etki, H3b), acil uzaktan eğitim sistemini kullanımına ilişkin tutumlarını (tatmin) olumlu yönde etkiler.

H4: Kullanıcıların acil uzaktan eğitim sisteminin kullanıma yönelik tutumlanı (tatmin), acil uzaktan eğitime yönelik teknolojiyi niyetlerini olumlu yönde etkilemektedir.

H5: Kullanıcıların uzaktan eğitim sistemine ilişkin öznel normları (dış etki, H5a, kişilerarası etki, H5b), acil uzaktan eğitim sistemini kullanımına ilişkin niyetlerini olumlu yönde etkiler.

H6: Kullanıcıların uzaktan eğitim sistemine ilişkin algılanan davranış kontrolü, kullanıcıların bu sistemi kullanmasına yönelik niyetini olumlu etkiler.

H7: Kullanıcıların uzaktan eğitim sistemini kullanmalarına yönelik tutumları, bu sistemi kullanma davranışlarını olumlu yönde etkileyecektir.

\subsection{Katılımcılara ait Demografik Özellikler}

Tablo 1: Katılımcılara Yönelik Demografik Özellikler

\begin{tabular}{llll}
\hline Demografik Değişkenler & Frekans & Yüzde \\
\hline \multirow{2}{*}{ Cinsiyet } & Erkek & 234 & 52.7 \\
& Kadın & 210 & 47.3 \\
\hline \multirow{4}{*}{ Yaş } & 18-25 yaş aralığında & 18 & 4.1 \\
& 26-35 yaş aralığında & 177 & 39.9 \\
& 36-45 yaş aralığında & 134 & 30.2 \\
& 46-55 yaş aralığında & 84 & 18.9 \\
& 56 ve üzeri & 32 & 7.0 \\
\hline
\end{tabular}




\begin{tabular}{llll}
\hline \multirow{3}{*}{ Eğitim } & Fakülte mezunu & 27 & 6.1 \\
& Yüksek lisans mezunu & 171 & 38.5 \\
& Doktora ve diğerleri & 246 & 55.4 \\
\hline \multirow{4}{*}{ Gelir } & $0-7000$ TL & 193 & 43.5 \\
& $7001-9000$ TL & 127 & 28.6 \\
& $9001-11000$ TL & 78 & 17.6 \\
& $11001-13000$ TL & 17 & 3.8 \\
& 13001 TL ve üzeri & 29 & 6.5 \\
\hline \multirow{3}{*}{ Pozisyon } & Çalışan / Personel & 332 & 74.8 \\
& Orta kademe yönetici & 81 & 18.2 \\
& Üst yönetici & 31 & 7 \\
\hline \multirow{3}{*}{ Çalışma } & $1-5$ yıl aras1 & 212 & 47.7 \\
Süresi & 6-10 yıl arası & 127 & 28.6 \\
& $11-15$ yıl arası & 47 & 10.6 \\
& $16-20$ yıl arası & 34 & 7.7 \\
& 21 ve üzeri yıllar & 24 & 5.4 \\
\hline \multirow{2}{*}{ Medeni Hal } & Bekâr & 128 & 28.8 \\
& Evli & 316 & 71.2 \\
\hline
\end{tabular}

Tablo 1'de de gösterildiği üzere araştırmaya katılan katılımcıların \%52.,7'si ( $n=234$ ) erkek, \%47.3'ü $(n=210)$ kadındır. \%4.1'i ( $n=18) 18$ ile 25 yaş aralığında, \%39.9’u u $(n=177) 26$ ile 35 yaş aralığında, \%30.2'si $(n=134) 36$ ile 45 yaş aralığında, \%18.9’u $(n=84) 46$ ile 55 yaş aralığında ve \%7.0’1 $(n=32)$ ise 56 ve üzeri yaşındadır. Katılımcıların \%6,1’i $(n=27)$ lisans mezunu; \% 38,5’i $(\mathrm{n}=171)$ yüksek lisans mezunu; \% 55,4'ü $(\mathrm{n}=246)$ doktora ve üzeri eğitim seviyesine sahiptir. Kat1lımciların \%43,5'i (n=193) 0 ile 7000 TL arasında; \%28,6's1 $(n=127) 7001$ ile 9000 TL arasında; \%17,6'sı ( $n=78) 9001$ ile 11000 TL; \%3,8’i $(n=17) 13001$ TL ve üzeri \%6,5'i $(n=29)$ aylık gelire sahiptir. Katılımcıların \%74,8'i (n=332) hizmet vermiş oldukları kurumda personel olarak görev yapmakta olup idari bir yetkiye sahip olmamaktadır. Katılımcıların \%18,2'si (n=81) orta kademe yöneticisi, \%7'si $(\mathrm{n}=31)$ üst düzey yöneticisi olarak görev yapmaktadır. 
Katılımcıların mevcut iş yerlerinde çalışma süresine göre $\% 47,7$ 'si $(n=212) 1$ ile 5 yıl arasında, \%28,6's1 (n=127) 6 ile 10 yıl arasında, \%10,6's1 (n=47) 11 ile 15 y1l arasinda, \%7,7'si $(n=34) 16$ ile 20 yıl arasında ve $\% 5,4$ 'ü $(n=24)$ katılımcı ise 21 yıl ve üzeri şeklindedir. Araştırmaya katılan gönüllü kişilerin \%28,8'i (n=128) bekâr, \%71,2'si (n=316) evlidir.

\subsection{Araştırmanın Değişkenleri}

Araştırmaya ait algılanan fayda, algılanan kullanım kolaylığı, öznel norm, davranışa yönelik tutum, algılanılan davranışsal kontrol, davranışa yönelik niyet, gerçekleşen davranış değişkenlerine ait soru maddeleri farklı kaynaklardan elde edilmiştir. Bu değişkenlere ait temel bilgiler aşağıda sunulmuştur.

Algılanan Fayda: Algılan fayda değişkenine ait sorular için Davis (1989) tarafindan geliştirilen, Teo (2012) tarafından kullanılan "Teknoloji Kabul Modeli” içeriğinde sıklıkla kullanılan soru ifadelerinden faydalanılmıştır. Toplamda üç ifade mevcuttur. İfadelerden birisi şu şekildedir: «Uzaktan eğitim sistemi, verimliliğimi artıracaktır». Cevaplar 5'li Likert ölçeğine göre elde edilmiştir (1. Kesinlikle Katılmıyorum $\rightarrow$ 5. Kesinlikle Katılıyorum). Ölçeğin güvenirlik katsayısı 0.95 'dir.

Algılanan Kullanım Kolaylığı: Algılan Kullanım Kolaylığı değişkenine ait sorular için Davis (1989) tarafından geliştirilen, Teo (2012) tarafindan kullanılan "Teknoloji Kabul Modeli" içeriğinde sıklıkla kullanılan soru ifadelerinden faydalanılmıştır. "Uzaktan eğitim sistemi ile etkileşimim açık ve anlaşılırdır» şeklinde olmak üzere toplamda üç ifade mevcuttur. Cevaplar 5'li Likert ölçeğine göre elde edilmiştir (1. Kesinlikle Katılmıyorum $\rightarrow$ 5. Kesinlikle Katılıyorum). Ölçeğin güvenirlik katsayısı 0.91'dir.

Öznel Norm: Öznel Norm Değişkeninin alt maddelerini oluşturan Kişiler Arası Etki ve Dış Etki değişkenine ait sorular Bhattacherjee (2000) tarafından geliştirilen Türkçe'ye geçerlilik ve güvenirliliği Çelik (2018) tarafından kullanılan soru ifadelerinden faydalanılmıştır. Cevaplar 5'li Likert ölçeğine göre elde edilmiştir (1. Kesinlikle Katılmıyorum $\rightarrow$ 5. Kesinlikle Katılıyorum). Kişiler arası etki değişkenine ait örnek soru ifadesi «Arkadaşlarım uzaktan eğitim sistemini kullanmam gerektiğini düşünürüm» şeklindedir. Dış etki değiş̧enine ait örnek soru ifadesi 
«Uzmanlar uzaktan ĕgitim sistemi kullanmakla alakalı olumlu düşüncelere sahiptir» şeklindedir. Ölçeğin güvenirlik katsayısı $0.90 / 0.81$ 'dir.

Davranışa Yönelik Tutum (Tatmin): Tatmin değişkeni ile ilgili sorular Oliver (1980) ve Spreng ve diğerleri, (1996) tarafindan kullanılan Türkçe’ye geçerlilik ve güvenirliliği Çelik (2018) tarafından kullanılan 3 soru ifadelerinden faydalanılmıştır. Cevaplar 5'li Likert ölçeğine göre elde edilmiştir (1. Kesinlikle Katılmıyorum $\rightarrow$ 5. Kesinlikle Katılıyorum). «Uzaktan eğitim sisteminin performansından memnunum.» «Uzaktan ĕgitim sistemini kullanma kararım akıllıca oldu» şeklinde örnek soru maddeleri mevcuttur. Ölçeğin güvenirlik katsayısı 0.87 'dir.

Algılanan Davranışsal Kontrol: Lee (2009) tarafından geliştirilen ve Doğan ve arkadaşları (2015) tarafindan kullanılan 2 maddelik soru ifadesi kullanılmıştır. Bu değişkene ait örnek soru ifadesi «Uzaktan eğitim bilgi sistemini kullanmak için gerekli bilgiye sahip olduğumu düşünüyorum» şeklindedir. Ölçeğin güvenirlik katsayısı 0.68-0.90’dır.

Davranışsa Yönelik Niyet: Algılan fayda değişkenine ait sorular için Davis (1989) tarafindan geliştirilen, Teo (2012) tarafından kullanılan "Teknoloji Kabul Modeli” içeriğinde sıklıkla

kullanılan soru ifadelerinden faydalanılmıştır. Toplamda üç ifade mevcuttur. Örnek bir araştırma sorusu «uzaktan eğitim sistemini kendi kontrolümde kullandığımı düşünüyorum» Cevaplar 5'li Likert ölçeğine göre elde edilmiştir (1. Kesinlikle Katılmıyorum $\rightarrow$ 5. Kesinlikle Katılıyorum). Ölçeğin güvenirlik katsayısı 0.95 ' dir.

Gerçekleşen Davranış: Laderer ve diğerleri (2003) ve Hu ve diğerleri (2002)'nin araştırmasında kullanılmış Türkçe’ye Çam (2012) tarafında uyarlanmış ifadelerden faydalanılmıştır. Toplamda dört ifade mevcuttur. Örnek İfadelerden birisi «Uzaktan ĕgitim sistemini sık slk kullanabilirim» şeklindedir. $\mathrm{Bu}$ değişkene ait son iki madde ters çevrilerek analiz süreci gerçekleştirilmiştir. Cevaplar 5'li Likert ölçeğine göre elde edilmiştir (1. Kesinlikle Katılmıyorum $\rightarrow$ 5. Kesinlikle Katılıyorum). Ölçeğin güvenirlik katsayısı 0.68-0.70 arasındadır.

\subsection{Geçerlilik ve Güvenirlik}

Araştırmanın analiz sonuçlarının geçerliliğini ve güvenirliği test etmek amacıyla öncelikle doğrulayıcı faktör analizi yöntemi kullanılmıştır. Doğrulayıcı faktör analizi, literatüre göre 
hazırlanmış ölçme araçlarının, ölçülmek için hazırlanan araştırma modeli temelinde, elde edilen veriler neticesinde yapı geçerliliğinin sağlanması, ölçme araçlarının literatürde belirtildiği doğrultudaki bilgilerin doğruluğunu test etmek amacıyla kullanılmaktadır (Brown ve Moore, 2012). Değişkenlerin yapı geçerliliğini incelemek için hem tek faktörlü doğrulayıcı faktör analizi hemde çok düzeyli doğrulayıcı faktör analizleri gerçekleştirilmiştir. Kline (2011) araştırması temel alınarak model uyum indeksleri ele alınmıştır. Model uyum indekslerinden adjusted goodness-offit index (AGFI), Normed fit index (NFI), Comparative fit indeks (CFI), Goodness-of-fit indeks (GFI), root mean square error of approximation (RMSEA) değerlerine yer verilmiştir. Yapılan analiz neticesinde uyum indekslerinin istenilen düzeyde olduğu sonucuna ulaşılmıştır. Değişkenlere ait uyum indeksleri sonuçları Tablo 2'de belirtilmiştir.

Tablo 2: Değişkenlere ait Doğrulayıcı Faktör Analiz Sonuçları

\begin{tabular}{lccccccc}
\hline & $\mathrm{x}^{2}$ Idf & NFI & GFI & CFI & AGFI & TLI & RMSEA \\
Algılanan Fayda & 3.040 & 0.994 & 0.993 & 0.996 & 0.966 & 0.989 & 0.068 \\
Algılanan & & & & & & & \\
Kullanım & 0.914 & 0.998 & 0.998 & 1.000 & 0.990 & 1.000 & 0.000 \\
Kolaylığ & & & & & & & \\
Öznel Norm(Kişilerarası Etki ve Dış Etki) & & & & & \\
Kişilerarası Etki & 3.255 & 0.994 & 0.993 & 0.996 & 0.964 & 0.987 & 0.071 \\
$\begin{array}{l}\text { Dış Etki } \\
\text { Tatmin }\end{array}$ & 2.550 & 0.992 & 0.994 & 0.995 & 0.972 & 0.986 & 0.059 \\
Gerçekleşen & 0.792 & 0.998 & 0.998 & 1.000 & 0.991 & 1.002 & 0.000 \\
Davranış & 1.318 & 0.997 & 0.999 & 0.999 & 0.985 & 0.996 & 0.027 \\
\hline
\end{tabular}

Araştırma sonucunda, literatür temelinde oluşturulan kavramsal model ilde ile iç tutarlılığını test etmek için üç farklı farklı aşamalı doğrulayıcı faktör analizi yapılmıştır. Doğrulayıcı faktör analizi sonucuna göre, göre, Tablo 3, Model 1'de bütün gözlenen değişkenler bir faktör altında toplanılarak analiz süreci gerçekleştirilmiştir. Tablo 3, Model 2'de ise, gözlenen değişkenler üç farklı faktör şeklinde (1. faktör, dışsal değişkenler ele alınmıştır (algılanan fayda, algılanan kullanım kolaylığı, kişilerarası etki, dış etki, algılanan davranışsal kontrol); araştırma modeli temelinde hem dışsal hem de içsel değişken özelliğine sahip olduğu düşünülen değişkenler 2.faktör 
(tatmin ve davranışa yönelik niyet), 3. Faktör ise içsel değişken olarak (gerçekleşen davranış) ele alınarak analiz gerçekleştirilmiştir. Tablo 2, Model 3'te araştırma modeli kapsamında belirtilen 8 farklı değişken ayrı ayrı ele alınarak analiz süreci gerçekleştirilmiştir. Analiz sonucunda, araştırmaya ait teorik model ile araştırma kapsmaında toplanılan veriler arasında yeterli bir uyumun olduğu sonucuna ulaşılmıştır $\left(\mathrm{x}^{2} \backslash \mathrm{df}=3.227\right.$, GFI=0,889, CFI, 0,884, IFI= 0,942, AGFI=0,848, RMSEA=0,071).

Tablo 13: Araştırma modeline ait doğrulayıcı faktör uyum endeksleri sonuçları

\begin{tabular}{lcccccc}
\hline & $\mathrm{x}^{2} \backslash \mathrm{df}$ & GFI & CFI & IFI & AGFI & RMSEA \\
Model 1 (Tek Faktör) & 13.047 & 0.613 & 0.620 & 0.621 & 0.536 & 0.165 \\
Model 2 (Üç Faktör) & 12.370 & 0.621 & 0.663 & 0.664 & 0.539 & 0.160 \\
Model 3 (Sekiz Faktör) & 3.227 & 0.889 & 0.884 & 0.942 & 0.848 & 0.071 \\
\hline
\end{tabular}

Son olarak ise Tablo 4'te belirtilmekte olan korelasyon analizi yapılmıştır. Araştırmanın değişkenlerine ait ortalama standart sapma ve güvenirlik katsayısına yer verilmiştir. Araştırmanın değişkenlerine ait geçerlilik ve güvenirlik testleri tamamlanmıştır.

Tablo 4: Ortalama, Standart Sapma Değerleri ve Korelasyon Katsayısı

\begin{tabular}{|c|c|c|c|c|c|c|c|c|c|c|}
\hline & Ort. & S.S & $\mathrm{AF}$ & AKK & $\mathrm{T}$ & $\mathrm{KE}$ & $\mathrm{DE}$ & ADK & DYN & GD \\
\hline $\mathrm{AF}$ & $\begin{array}{l}3.29 \\
8\end{array}$ & $\begin{array}{l}1.20 \\
1\end{array}$ & $\begin{array}{l}1(0.89 \\
4)\end{array}$ & & & & & & & \\
\hline $\mathrm{AK}$ & 4.15 & 0.89 & $0.393 *$ & & & & & & & \\
\hline K & 9 & 8 & * & 6) & & & & & & \\
\hline $\mathrm{T}$ & $\begin{array}{l}3.45 \\
7\end{array}$ & $\begin{array}{l}1.05 \\
7\end{array}$ & $\begin{array}{l}0.698 * \\
*\end{array}$ & $\begin{array}{l}0.464 * \\
*\end{array}$ & $\begin{array}{l}1(0.82 \\
5)\end{array}$ & & & & & \\
\hline KE & $\begin{array}{l}3.35 \\
9\end{array}$ & $\begin{array}{l}1.08 \\
8\end{array}$ & $\begin{array}{l}0.517 * \\
*\end{array}$ & $\begin{array}{l}0.403 * \\
*\end{array}$ & $\begin{array}{l}0.626^{*} \\
*\end{array}$ & $\begin{array}{l}1(0.90 \\
9)\end{array}$ & & & & \\
\hline $\mathrm{DE}$ & $\begin{array}{l}3.09 \\
3\end{array}$ & $\begin{array}{l}1.06 \\
5\end{array}$ & $\begin{array}{l}0.637 * \\
*\end{array}$ & $\begin{array}{l}0.336^{*} \\
*\end{array}$ & $\begin{array}{l}0.676^{*} \\
*\end{array}$ & $\begin{array}{l}0.551 * \\
*\end{array}$ & $\begin{array}{l}1(0.80 \\
2)\end{array}$ & & & \\
\hline $\begin{array}{l}\mathrm{AD} \\
\mathrm{K}\end{array}$ & $\begin{array}{l}3.76 \\
8\end{array}$ & $\begin{array}{l}1.14 \\
3\end{array}$ & $\begin{array}{l}0.309 * \\
*\end{array}$ & $\begin{array}{l}0.375 * \\
*\end{array}$ & $\begin{array}{l}0.441 * \\
*\end{array}$ & $\begin{array}{l}0.307 * \\
*\end{array}$ & $\begin{array}{l}0.326^{*} \\
*\end{array}$ & $\begin{array}{l}1(0.54 \\
9)\end{array}$ & & \\
\hline
\end{tabular}




\begin{tabular}{|l|l|l|l|l|l|l|l|l|l|l|}
\hline $\begin{array}{l}\text { DY } \\
\text { N }\end{array}$ & $\begin{array}{l}3.53 \\
8\end{array}$ & $\begin{array}{l}1.13 \\
7\end{array}$ & $\begin{array}{l}0.595 * \\
*\end{array}$ & $\begin{array}{l}0.472 * \\
*\end{array}$ & $\begin{array}{l}0.658^{*} \\
*\end{array}$ & $\begin{array}{l}0.558^{*} \\
*\end{array}$ & $\begin{array}{l}0.555^{*} \\
*\end{array}$ & $\begin{array}{l}0.446 * \\
*\end{array}$ & $\begin{array}{l}1(0.93 \\
6)\end{array}$ & \\
\hline GD & 3.36 & 0.95 & $0.624 *$ & $0.383^{*}$ & $0.682^{*}$ & $0.519 *$ & $0.569^{*}$ & $0.346^{*}$ & $0.784 *$ & $1(0.73$ \\
& 7 & 4 & $*$ & $*$ & $*$ & $*$ & $*$ & $*$ & $*$ & $4)$ \\
\hline
\end{tabular}

Correlation is significant at the 0.01 level (2-tailed).** Parantez içi Crobach Alpha değerini göstermektedir. Ort.: Ortalama, S.S.: Standart Sapma; AF: Algılanılan Fayda; AKK: Algılanılan Kullanım Kolaylı̆̆ı; T: Tatmin; KE: Kişilerarası Etki: DE: Dış Etki; ADK: Algılanılan Davranış Kontrolü; DYN: Davranışa Yönelik Niyet; GD: Gerçekleşen Davranış

\subsection{Sonuçlar}

\subsubsection{Yapısal Eşitlik Modeli}

Araştırma modeli kapsamında oluşturulan alt değişkenlerde dâhil olmak üzere toplamdaki 9 varsayımın sınanması, değişkenler arasındaki neden sonuç ilişkisinin ortaya konulması için yapısal eşitlik modeli uygulanmıştır. Yapısal eşitlik modelinde uyum indekslerine bakılarak araştırmanın analizlerinin istenilen sonuca ulaşılıp ulaşılmadığı noktasında karar verilmektedir. Tablo 5'de hem uyum iyiliği ölçütleri hem de araştırmanın analizi sonuçlarına dayalı olarak faktörel uyum iyiliği değerleri gösterilmektedir. Bu sonuca göre, araştırmanın analiz sonuçlarının uyum iyilikleri sınırları arasında yer aldığı ve analiz çıktılarının kabul edilebilir bir niteliğe sahip olduğu görülmektedir.

Tablo 5: Araştırma Modelinin Uyum iyiliği Ölçütleri

\begin{tabular}{lccc}
\hline Uyum Ölçüsü & İdeal Uyum Değerleri & $\begin{array}{c}\text { Kabul Edilebilir } \\
\text { Uyum Değerleri }\end{array}$ & $\begin{array}{c}\text { Faktör Uyum } \\
\text { Değerleri }\end{array}$ \\
\hline $\mathrm{x}^{2}$ & $(\mathrm{P}>0,05)$ & & 696.587 \\
$\mathrm{x}^{2} / \mathrm{df}$ & $\mathrm{x}^{2} / \mathrm{df} \leq 2$ & $\mathrm{x}^{2} / \mathrm{df} \leq 5$ & 3.317 \\
$\mathrm{RMSEA}$ & $0.00<\mathrm{RMSEA}<0.05$ & $0.00<\mathrm{RMSEA}<0.10$ & 0.072 \\
$\mathrm{AGFI}$ & $0.90<\mathrm{AGFI}<1.00$ & $0.80<\mathrm{AGFI}<0.90$ & 0.840 \\
$\mathrm{CFI}$ & $0.95<\mathrm{CFI}<1.00$ & $0.90<\mathrm{CFI}<0.95$ & 0.936
\end{tabular}




$\begin{array}{llll}\text { TLI } & 0.95<\mathrm{TLI}<1.00 & 0.90<\mathrm{TLI}<0.95 & 0.923 \\ \text { RFI } & 0.90<\mathrm{RFI}<1.00 & 0.85<\mathrm{RFI}<0.90 & 0.894\end{array}$

AMOS 20 paket programından test edilen modelin Ki-kare değeri 696. 587, serbestlik derecesi 210 ve anlamlılık düzeyi 0.00 olarak hesaplanmıştır. Ki-kare testi, veri ile model arasındaki uyumun testidir. Bu test, model ile gözlenen değişkenlerin kovaryans yapıları arasında bir farkın olup olmadığını test etmektedir (Çam, 2016: 219).

Tablo 5'te $\mathrm{x}^{2}$ /df değerinin 3.317 düzeyinde olduğu görülmektedir. RMSEA 0 ile 1 arasında değerler almaktadır. RMSEA'nın 0.05 'ten küçük veya eşit olması mükemmel uyum, 0.008'e kadar olan değerler kabul edilebilir uyumu ve 0.10 ve üzeri değerler ise zayıf uyumu göstermektedir. YEM modeli uyum ölçülerine göre RMSEA değerinin 0. 072 olduğu görülmektedir. Model uyum ölçütlerinde GFI: 0.879 ve AGFI: 0.840 olarak ölçümlenmiştir. Modelin sıfir hipotezi ile uyumunu araştıran NFI değeri 0.912 elde edilmiştir. Örneklem büyüklüğüne duyarlı olan ve uyum iyiliğini belirten CFI indeksi 0.936 değerindedir. TLI indeksi 0.923 değerindedir. RFI değeri ise 0.894 değerindedir.

Model uyum iyiliği ölçülerine ait değerlendirmeler yapıldıktan sonra ölçüm hatalarının değerlendirilmesi yapılmıştır. Yapısal eşitlik modelinin en önemli özelliği ölçüm hatalarını dikkate alarak ve bu hataların modelde belirtilmesi sağlanarak sonuca ulaşılmasıdır. Yapısal eşitlik modelinin AMOS çıktısı standardize edilmiş bir şekilde Şekil 2'de standandardize edilmemiş hali ise Şekil 3'de sunulmuştur. 
Şekil 2: Yapısal Eşitlik Modeli Standardize Edilmiş Değerlere ait AMOS Çıktısı

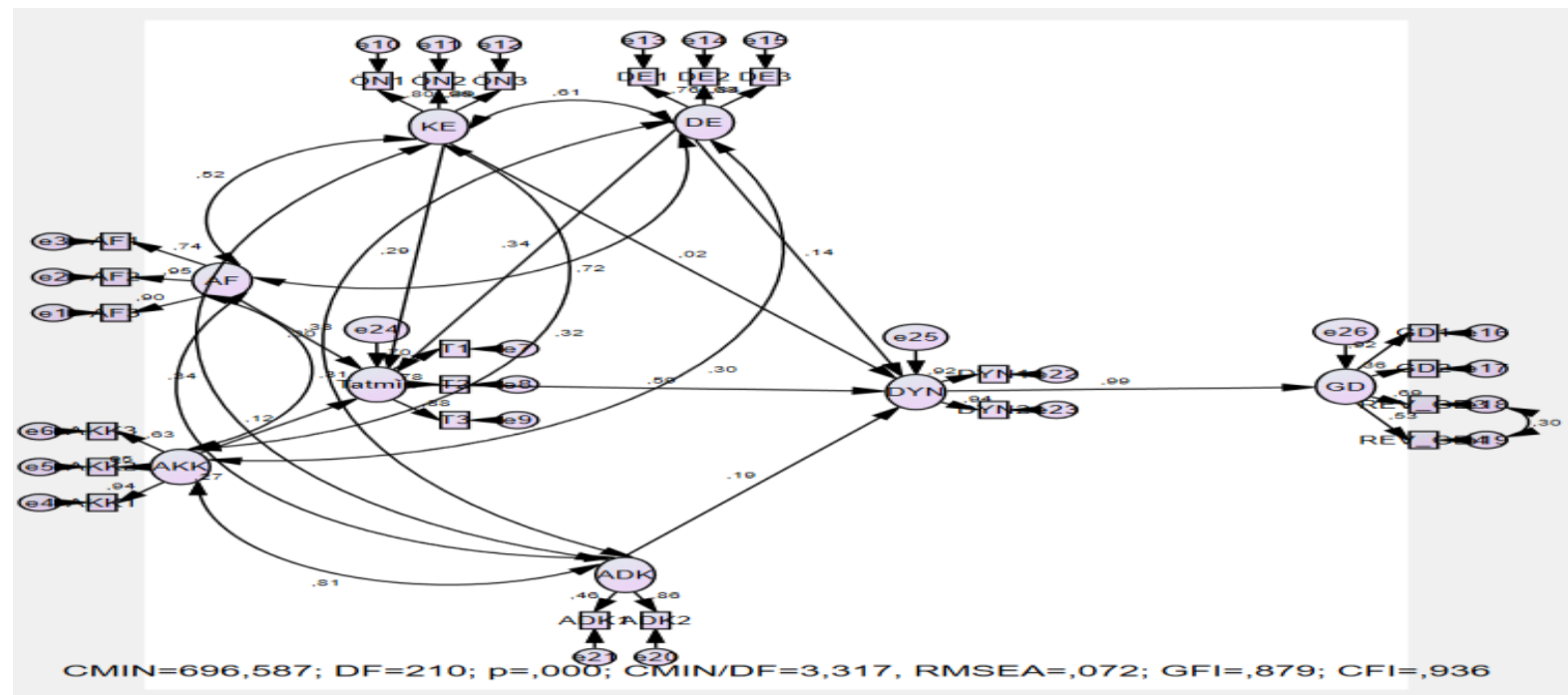

Şekil 3: Şekil 2: Yapısal Eşitlik Modeli Standardize Edilmemiş Değerlere ait AmMOS Çıktısı

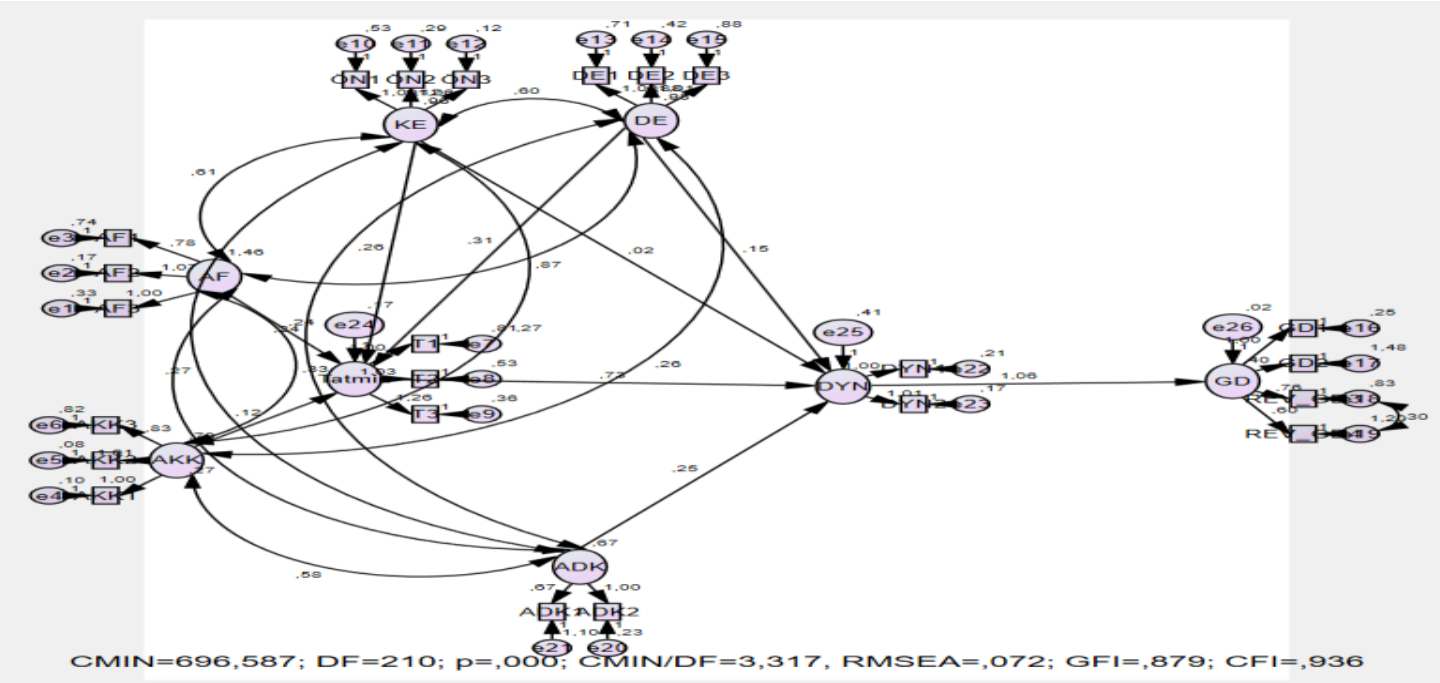

Yapısal eşitlik modeli, içsel ve dışsal gizil değişkenlerin aynı anda içinde barındırması sebebiyle faktör ve yol analizlerinin birleşmiş halidir. Bu model en temel anlamı ile gözlenen ve gözlemlenmeyen değişkenler arasındaki sebep-sonuç ilişkisini gösteren oklardan oluşmaktadır. Araştırmanın yapısal modelinde şekil 2 ve Şekil 3'de gösterildiği üzere 5 adet dışsal gizil değişken bulunmaktadır. 1 adet içsel gizil değiş̧en, 2 adet ise hem içsel hem de dışsal gizil değişken mevcuttur. 
Tablo 6'da, standart ve standart olmayan regresyon yükleri, hipotezlerin değerlendirilmesinde kullanılacak değerler, değişkenler arası ilişkilerin anlamlı olup olmadıkları ve ilişkilerin istenilen yönde olup olmadığı değerlendirilmiştir. Bu değerlendirme de ise AMOS programının her bir ilişki için ortaya koyduğu $\mathrm{p}$ değerinden yararlanılmıştır. Bununla beraber $\mathrm{p}<0,05$ düzeyinde 0,05 'ten küçük olan p değeri anlamlı olarak değerlendirilmiştir (Çam, 2012). AMOS programının kritik oran (Critical Ratio) olarak modelin çıktısında elde edilen t değer ile aynı değerler olduğunu bulmuştur. Bununla beraber tek modelde $t$ değerini $t=\beta$ / S.E formülü ile ifade etmişsir. Kritik oranın formülü ise AMOS'ta $\beta$ /S.E şeklinde gösterilmektedir. Bu nedenle kritik oran $t$ değeri olarak düşünülmüştür. Buna göre $t$ değerleri 1,65 ve üzeri $t$ değerleri $p<0,05$ düzeyinde anlaml olarak kabul edilmiştir (Çam, 2016: 222).

Tablo 6: Modelin Hipotezlerinin Değerlendirilmesi

\begin{tabular}{lcccccc}
\hline $\begin{array}{c}\text { Modeldeki Yapısal } \\
\text { İlişkiler }\end{array}$ & $\begin{array}{c}\text { Standart } \\
\text { Olan } \\
\text { Yükler }\end{array}$ & $\begin{array}{c}\text { Standart } \\
\text { Olmayan } \\
\text { Yükler }\end{array}$ & $\begin{array}{c}\text { Standart } \\
\text { Hata }\end{array}$ & $\begin{array}{c}\text { Critical } \\
\text { Ratio t } \\
\text { Değeri }\end{array}$ & $\begin{array}{c}\text { P } \\
\text { Değeri }\end{array}$ & $\begin{array}{c}\text { Hipotez } \\
\text { Sonucu }\end{array}$ \\
\hline Tatmin <--- AF & 0.326 & 0.238 & 0.040 & 5.911 & 0.000 & Kabul \\
Tatmin <--- AKK & 0.122 & 0.122 & 0.035 & 3.490 & 0.000 & Red \\
Tatmin <--- KE & 0.289 & 0.259 & 0.043 & 6.082 & 0.000 & Kabul \\
Tatmin <--- DE & 0.343 & 0.305 & 0.059 & 5.131 & 0.000 & Kabul \\
DYN <---Tatmin & 0.590 & 0.726 & 0.113 & 6.436 & 0.000 & Kabul \\
DYN <--- DE & 0.137 & 0.150 & 0.082 & 1.829 & 0.067 & Red \\
DYN <--- KE & 0.018 & 0.019 & 0.058 & 0.334 & 0.738 & Red \\
DYN <--- ADK & 0.188 & 0.249 & 0.056 & 4.449 & 0.000 & Kabul \\
GD <--- DYN & 0.994 & 1.058 & 0.333 & 32.433 & 0.000 & Kabul \\
\hline AKK: Algılanan Kullanım Kolaylı̆ı̆; AF: Algılanan Fayda; DE: Dış Etki; KE: Kişilerarası Etki; \\
DYN: Davranışa Yönelik Niyet; ADK: Algılanan Davranışsal Kontrol; GD: Gerçekleşen Davranış
\end{tabular}


Tablo 7'de görüldüğü üzere H5a ve H5b ile ifade edilen "davranışa yönelik niyet <--- dış etki” ve "davranışa yönelik niyet <--- kişilerarası etki" ile ifade edilen ilişkinin $\mathrm{p}<0.05$ düzeyinde anlamsız çıktığı görülmüştür. Bu nedenle modelde yer alan H5a ve H5b hipotezi istatistiksel olarak desteklenmediği için red edilmiştir. H1, H2, H3A, H3B, H4, H6 ve H7 hipotezleri p<0,05 düzeyinde anlamlı çıkmıştır. İstatistiki olarak desteklendiği için bu hipotezler kabul edilmiştir.

\section{Sonuç}

$\mathrm{Bu}$ araştırma, COVID-19 salgını süresinde, akademisyenlerin acil uzaktan eğitim sistemlerinin kullanımına yönelik algılarını ölçmek amacıyla gerçekleştirilmiştir. Akademisyenlerin acil uzaktan eğitim sistemini kullanmalarını etkileyen unsurlar nelerdir? Akademisyenlerin algılarını etkileyen unsurlar davranışlarını nasıl şekillendirmektedir? Araştırma sorularına yönelik cevap aranmıştır. Bu kapsamda, Yüksek Öğretim Kurumuna bağlı üniversitelerde görev yapmakta olan 444 akademisyene kartopu örneklem ve kolayda örneklem yöntemi kapsamında çevrimiçi veri toplama yöntemi kullanılarak ulaşılmıştırç

Araştırma sonucunda, algılanan fayda (H1), algılanan kullanım kolaylığg (H2), öznel normların (H3a: kişilerarası, H3b: dış etki) kullanıcı tatminini pozitif ve olumlu yönde etkilediği; kullanıcıların sahip olmuş olduğu tatmin duygsunun, kullanılmakta olan uzak eğitim sistemine yönelik kullanım niyetlerini artırıcı bir unsur olduğu sonucuna ulaşılmıştır (H4). Aynı zamanda uzaktan eğitim sistemi kullanıcılarının, system kullanımına yönelik bir sistemi kontrol edebilecekleri algısına sahip olduklarında, bu durumun kullanım niyetlerini pozitif yönde etkilediği (H6), davranışsal niyetinde gerçekleşen davranışı olumlu yönde etkilediği sonucuna ulaşılmıştır (H7). Fakat öznel normun (H5a: kişilerarası, H5b: dış etki acil uzaktan eğitim sistemini kullanmalarına yönelik bir etkisi olmadığ1 sonucuna ulaşılmıştır. H1, H2, H4, H6 ve H7 literatürde mevcut bulunan Doğan ve diğ., (2015), Sukendro ve diğg, (2020), Lazim ve diğ, (2020), Girsh ve diğ., (2021) tarafından yürütülen araştırmalar ile benzer sonuca ulaşılarak literature tarafından desteklenmektedir. Kişiler arası etki ile kullanılan teknolojiye yönelik tutum arasın 
olumlu bir ilişki bulunurak bu araştırma tarafından Kabul edilirken, Farooq ve diğ., (2020) tarafından yürütülen araştırma da bu iki değişken arasında bir ilişki olmadığı sonucuna ulaşılmıştır. H5b , Çelik ve Sökmen (2018) tarafindan yürütülen araştırmada benzer sonuca ulaşılırken H5a kapsamında farklı sonuçlar elde edilmiştir.

Araştırma sonucuna gore, akademisyenlerin acil uzaktan eğitim esnasında kullanmış oldukları sistemlere dayalı olarak algıladıkları fayda, algıladıkları kullanım kolaylığının tatminlerini olumlu yönde etkilendiği, tatmine dayalı bu tutumun ise uzaktan eğitim sistemlerine yönelik kullanım niyetini olumlu yönde etkilemektedir. Aynı zamanda bu süreçte, teknoloji Kabul modeli çerçevesinde gerçekleşen davranışa yönelik öncüllerde bir arada değerlendirildiğinde, Türkiye bağlamında akademisyenlerin acil uzaktan eğitim sürecine hızlı bir şekilde uyum sağladıkları, süreç içerisinde teknoloji kullanımına yönelik olumlu yönde yetkinliğe sahip oldukları bulgulanmıştır. Fakat planlı davranış teorisi kapsamında ele alınan öznel norm değişkenlerinin kullanıcı niyetlerine yönelik bir etkisi olmadığı sonucuna ulaşılmıştır. Bu durumun ise süreç ile alakası olduğu düşünülmektedir. Acil uzaktan eğitim sürecine plansız ve olağanüstü bir şekilde gerçekleşmesinden dolayı yargısal olarak zorunlu bir dönemden geçilmesinden kaynaklı olabilmektedir.

\section{Kaynakça}

Ajzen, I. (1991). The Theory of Planned Behavior. Organizational Behavior and Human Decision Processes, 50(2), 179-211.

Avc1, İ., ve Yıldız, E. (2021). Covid-19 Pandemi Sürecinde Uzaktan Eğitimi Kullanan Öğrencilerin Memnuniyet Ve Davranışlarının Teknoloji Kabul Modeli Çerçevesinde İncelenmesi. Gümüshane University Electronic Journal of The Institute of Social Science/Gümüshane Üniversitesi Sosyal Bilimler Enstitüsü Elektronik Dergisi, 12(3). 814-830. 
Bozkurt, A. (2020). Koronavirüs (Covid-19) Pandemi Süreci Ve Pandemi Sonrası Dünyada Eğitime Yönelik Değerlendirmeler: Yeni Normal Ve Yeni Eğitim Paradigması. Açıköğretim Uygulamaları Ve Araştırmaları Dergisi, 6(3), 112-142.

Bozkurt, A., Jung, I., Xiao, J., Vladimirschi, V., Schuwer, R., Egorov, G., ... Paskevicius, M. (2020). A Global Outlook To The İnterruption Of Education Due To COVID-19 Pandemic: Navigating In A Time of Uncertainty And Crisis. Asian Journal of Distance Education, 15(1), 1-126. Https://Doi.Org/10.5281/Zenodo.3878572.

Brown, T. A., ve Moore, M. T. (2012). Confirmatory factor analysis. Handbook of structural equation modeling, 361-379.

Conner, M., ve Armitage, C. J. (1998). Extending The Theory of Planned Behavior: A Review And Avenues For Further Research. Journal of Applied Social Psychology, 28(15), 1429-1464.

Çam, H. (2012). Türkiye'deki Üniversitelerde Bulut Bilişim Teknolojisinin Uygulanabilirliğinin Teknoloji Kabul Modeli Yaklaşımıyla Belirlenmesi. Yayımlanmamış Doktora Tezi), Atatürk Üniversitesi, Sosyal Bilimler Enstitüsü, Erzurum.

Çam, H. (2016). İşletmelerin Dış Kaynak Kullanımını Etkileyen Faktörlerin Yapısal Eşitlik Modeli Yaklaşımı ile Belirlenmesi. Gümüshane University Electronic Journal of The Institute Of Social Science/Gümïshane Üniversitesi Sosyal Bilimler Enstitüsü Elektronik Dergisi, 7(15). 211288.

Çelik, K. (2018). Genişletilmiş Teknoloji Kabul Modeli: Uzaktan Ĕgitim Öğrencileri Üzerine Bir Araştırma (Yayınlanmamış Doktora Tezi). Gazi Üniversitesi.

Çelik, K., eve Sökmen, A. (2018). Uzaktan Eğitime Devam Etme Niyetinin Anlaşılması: Genişletilmiş Teknoloji Kabul Modeli. Yönetim, Ekonomi ve Pazarlama Araştırmaları Dergisi, 2(3), 1-23.

Davis, F.D. (1989), "Perceived Usefulness, Perceived Ease Of Use, And User Acceptance Of İnformation Technology”, MIS Quarterly, Vol. 13, No. 3, Pp. 319-340.

Doğan, M., Rana, Ş., ve Yılmaz, V. (2015). İnternet Bankacılığına İlişkin Davranışların Planlanmış Davranış Teorisi Ve Teknoloji Kabul Modeli Kullanılarak Önerilen Bir Yapısal Eşitlik Modeliyle İncelenmesi. Uşak Üniversitesi Sosyal Bilimler Dergisi, 8(2), 1-22. 
Eken, Ö. Tosun, N., ve Eken, D. T. (2020). Covid-19 Salgını İle Acil ve Zorunlu Uzaktan Eğitime Geçiş: Genel Bir Değerlendirme. Milli Eğitim Dergisi, 49(1), 113-128.

Erten, S. (2002). Planlanmış Davranış Teorisi İle Uygulamalı Öğretim Metodu. Hacettepe Üniversitesi Edebiyat Fakültesi Dergisi, 19(2). 217-233.

Farooq, S., Ahmad, Z., ve Khan, M. S. (2021). A Technology Acceptance Model For E-Learning During COVID-19: Empirical Insight From Pakistan. Ilkogretim Online, 20(4).

Girish, V. G., Kim, M. Y., Sharma, I., ve Lee, C. K. (2021). Examining The Structural Relationships Among E-Learning İnteractivity, Uncertainty Avoidance, And Perceived Risks Of COVID-19: Applying Extended Technology Acceptance Model. International Journal of HumanComputer Interaction, 1-11.

Hong, X., Zhang, M., ve Liu, Q. (2021). Preschool Teachers' Technology Acceptance During The COVID-19: An Adapted Technology Acceptance Model. Frontiers In Psychology, 12. 1-11.

Kahya, V. (2021). Investigation of Compulsory Distance Education Practices With İntegrated Technology Acceptance Models During The Coronavirus (COVID-19) Pandemic. Business \& Management Studies: An International Journal, 9(2), 737-750.

Kline, R. B. (2011). Convergence Of Structural Equation Modeling And Multilevel Modeling.

Kürtüncü, M., \& Aylin, K. U. R. T. (2020). COVID-19 Pandemisi Döneminde Hemşirelik Öğrencilerinin Uzaktan Eğitim Konusunda Yaşadiklari Sorunlar. Avrasya Sosyal ve Ekonomi Araştırmaları Dergisi, 7(5), 66-77.

Lazim, C. S. L. M., Ismail, N. D. B., ve Tazilah, M. D. A. K. (2021). Application of Technology Acceptance Model (TAM) Towards Online Learning During Covid-19 Pandemic: Accounting Students Perspective. Int. J. Bus. Econ. Law, 24, 13-20.

Rini, G. P., \& Khasanah, I. (2021). Intention to Use Online Meeting Applications During Covid19 Pandemic: A Technology Acceptance Model Perspective. Jurnal Manajemen Dan Pemasaran Jasa, 14(1), 77-94.

Sukendro, S., Habibi, A., Khaeruddin, K., Indrayana, B., Syahruddin, S., Makadada, F. A., \& Hakim, H. (2020). Using An Extended Technology Acceptance Model to Understand Students' 
Use of E-Learning During Covid-19: Indonesian Sport Science Education Context. Heliyon, 6(11), E05410.

Teo, T. (2012). Examining The Intention To Use Technology Among Pre-Service Teachers: An İntegration Of The Technology Acceptance Model And Theory of Planned Behavior. Interactive Learning Environments, 20(1), 3-18.

Yörük, T., Akar, N., Ve Erdoğan, H. (2020). Öğrenme Yönetim Sistemi Kullanımını Etkileyen Faktörlerin Genişletilmiş Teknoloji Kabul Modeli Çerçevesinde Yapısal Eşitlik Modeli İle Analizi. Eskişehir Osmangazi Üniversitesi Sosyal Bilimler Dergisi, 21(2), 431-449. 